\title{
EPICTETO \\ Y LA REVALORACIÓN DE LA DESVERGÜENZA CÍNICA
}

\author{
JUAN HORACIO DE FREITAS ${ }^{1}$
}

\begin{abstract}
RESUMEN: El modo en que Epicteto recogió la herencia cínica es particularmente interesante, y no apenas por ser el único de los estoicos del cual se conserva un discurso exclusivamente dedicado al cinismo, sino ante todo por el complejo dispositivo a través del cual se logra dar un lugar fundamental al cinismo en la visión de mundo estoica, a la vez que se pone rigurosos límites a su propagación e impacto en el cuerpo social. La forma básica en la que funciona este dispositivo es remodelando hermenéuticamente al personaje cínico, no edulcorándolo u obviando su desfachatez, tal como suele sostenerse, sino más bien destacando su radical excepcionalidad, su extrema singularidad, siendo justo esta la que le permite, e incluso le exige, una conducta que sería inaceptable para el resto de los mortales. El objetivo del presente ensayo será, precisamente, detallar y explicar esta estrategia de recepción del cinismo propiamente epictetiana y comprender su función filosófica e ideológica en el contexto romano.
\end{abstract}

Palabras clave: cinismo - Epicteto - estoicización - ascesis - excepcionalidad.

ABSTRACT: The way in which Epictetus received the cynical inheritance is particularly interesting, not merely because he is the only one of the Stoics whose extensive and famous discourse on Cynicism is preserved, but above all because of the complex device through which he succeeds in giving a fundamental place to Cynicism in the Stoic worldview, while at the same time placing rigid limits on its propagation and impact on the social body. This device works by hermeneutically remodeling the cynical character,

${ }^{1}$ Universidad Católica Andrés Bello- Universidad Complutense de Madrid. E-mail: defreitas.jh@gmail.com; jdefreit@ucm.es

Fecha de recepción: 20/10/2021; fecha de aceptación: 9/12/2021.

DOI: https://doi.org/10.46553/sty.30.30.2021.p137-154

Stylos. 2021; 30 (30); pp. 137-154; ISSN: 0327-8859; E-ISSN: 2683-7900 
which does not consist of softening him, of smoothing his asperities or ignoring his impudence, as some have argued, but rather in highlighting his radical exceptionality, his extreme singularity, which is precisely what allows him, and even demands of him, a behavior that would be unacceptable for the rest of mortals. The aim of this paper will be, precisely, to point out and explain these properly Epictetian strategies of reception of Cynicism and to understand its philosophical and ideological function in the Roman context.

Keywords: Cynicism - Epictetus - stoicization - ascesis - exceptionality.

Un mecanismo estoico de proselitismo doctrinal consistió en demostrar la propia dignidad genealógica presentándose como el resultado de una reconocible tradición que tendría como origen a la siempre ejemplar figura de Sócrates. $^{2}$ Sin embargo, la cadena de sucesiones discipulares establecida para justificar su fundamento socrático no dejó de ser problemática, y no apenas por alguna polémica respecto a su verosimilitud cronológica ${ }^{3}$-que para lo que viene al caso importa poco-, sino ante todo porque los eslabones que, según ellos mismos, conectaban a Zenón de Citio, padre del estoicismo, con el filósofo ateniense eran polémicos en exceso, además de aparentemente di-

\footnotetext{
2 "They probably regarded Cynicism as representing in its purest form the ethical tradition of Socrates, and would be particularly anxious to show that they themselves were the direct inheritors of that tradition. Hence was constructed the «succession» Socrates-AntisthenesDiogenes-Crates-Zeno (...)" en DudLEY (1974: 2-3). En continuidad con esta idea: LONG (1988: 150-171); GARCÍA GUAL (2002: 31).

${ }^{3}$ El representante más renombrado de la tesis de la inverosimilitud cronológica de dicha sucesión filosófica es el propio Dudley, asunto al que dedica un extenso capítulo titulado "Antisthenes. No direct conexión with cynics. His ethics", en el célebre libro aquí previamente referenciado. También GIANNANTONI (1990: 223-233), LONG (2020: 50), BANNERT (1979: 49-53) y algunos otros eruditos modernos concuerdan con este parecer. No obstante, hay quienes defienden que dicha sucesión es real, independientemente de que la relación discipular haya sido directa o no, entre ellos encontramos a MOLES (2020: 146), FeliU (1977: 21), HöISTAD (1948: 10), quien se opone abiertamente a Dudley; GOMPERZ (2010: 163-164), LANDA (2015: 69-70), MÁRSICO (2019: 24-25), entre otros.
}

Stylos. 2021; 30 (30); pp. 137-154; ISSN: 0327-8859; E-ISSN: 2683-7900 
sonantes con la temperante ética estoica y, aún más, con los postulados vinculados a los compromisos familiares y ciudadanos que sostuvieron sus representantes más destacados de la época imperial. ${ }^{4}$ En efecto, la sucesión que va de Sócrates al maestro del pórtico está mediada por los tres personajes más destacados del cinismo: el meteco Antístenes, discípulo directo de aquél $;{ }^{5}$ el desterrado e icónico Diógenes de Sinope, presunto seguidor de este último, ${ }^{6}$ así como maestro del inaugurador - junto a Hiparquía de Maronea- de la desvergonzada canigamia ${ }^{7}$ a saber, Crates de Tebas, ${ }^{8}$ de quien se dice que, a su vez, fue el maestro del padre del estoicismo. ${ }^{9}$ De este modo, al tiempo que los estoicos celebraban tener como ancestro filosófico al gran personaje de la filosofía clásica, debían también lidiar de algún modo con la desfachatez cínica que era parte de su herencia. ${ }^{10}$

\footnotetext{
${ }^{4} \mathrm{Al}$ respecto conviene revisar los estudios de GRIFFIN (2020: 251-269), GoulET-CAZÉ (1990: 2720-2833), GOULET (1993: 419-443) y KRUEGER (2020: 291-314).

${ }^{5}$ Diógenes Laercio, VI 2 (2010: 209). También: Jenofonte, III, 11, 17 (1993: 145); Gnomologium Vaticanum 743, n. 4. En MARTín García (2008: p. 130).

${ }^{6}$ D. L., I 15, VI 21 (2010: 34, 215). También: Eusebio de Cesarea. Preparación evangélica XV 13, 8, p. 816 c; Eliano. Historia varia X 16; Jerónimo. Contra Joviniano II 14; Arriano. Diatribas de Epicteto III 24, 67-69, en MARTín GARCía (2008: 221-223).

${ }^{7}$ Sobre la canigamia: La Suda, s. v. Crates; Taciano. Discurso a los griegos 3, 3; Arriano. Diatriba de Epicteto III 22, 76; Teodoreto. Curación de las afecciones de los griegos XII 49; Clemente de Alejandría. Tapiz IV, XIX 121, 6. En MARTín GARCía (2008: 506-507).

${ }^{8}$ La Suda, s. v. Crates; Eusebio de Cesarea. Preparación evangélica XV 5, 11-12, p. 729 b-d, en MARTín García (2008: 500-501).

9 D. L., VII 2-4, $31-32$ (2010: 243-244, 252); La Suda, s. vv. "He tenido una feliz travesía...”; Eusebio de Cesarea. Preparación evangélica XV 13, 8, p. 816 c, en MARTín García (2008: 501-502).

${ }^{10}$ Ya se manifiesta en el estoicismo medio el esfuerzo de desembarazarse totalmente del lastre cínico, incluso eso significando la ruptura de la cadena de sucesiones que ligan a la sabiduría del pórtico con Sócrates. Tenemos el caso del libro primero de De Officiis, que, si bien tiene como autor a Cicerón, podemos suponer que se trata en este punto de un seguimiento de las ideas de Panecio; al respecto, véase: GRIFFIN (2020: 253); y BILLERBECK (2020: 271): "Nec vero audiendi sunt Cynici (...) (Y en verdad, los cínicos no son de oír)”; y más adelante: "Cynicorum vero ratio tota est eicienda; est enim inimica verecundia, sine qua nihil rectum ese potest, nihil honestum (La razón de los cínicos, entera debe ser rechazada, pues es enemiga de la verecundia, sin la cual nada puede ser recto; nada, honesto)", CICERÓN (2009: 56-57, 6566). Asimismo, es llamativo el testimonio de Filodemo, según el cual los estoicos procuraron negar la autenticidad de la escandalizante Constitución política de Diógenes para así desligar
}

Stylos. 2021; 30 (30); pp. 137-154; ISSN: 0327-8859; E-ISSN: 2683-7900 
No hubo apenas un modo de cargar con dicha herencia, y fácilmente se comprende esta falta de univocidad si se toma en consideración la ya de por sí ambivalente relación que tenía el propio Zenón con su maestro tebano, la cual oscilaba entre el aprendizaje y la resistencia, la admiración y el escándalo. ${ }^{11}$ Para ejemplificar estos diversos modos tendríamos que comenzar por el de Aristón de Quíos, quien tenía la intención de acercar las enseñanzas estoicas a la rudimentariedad cínica, ${ }^{12}$ mientras que en Cleantes y Crisipo observamos un claro distanciamiento de este conservadurismo aristoniano, sin dejar de ser cierto que aún se perciben rasgos cínicos en ambos, tanto en sus postulados filosóficos como en la tradición anecdótica que recoge parte de sus vidas; ${ }^{13}$ en Apolodoro de Seleucia, ya próximo al estoicismo medio,

su propia herencia de principios cínicos tan polémicos, cf. Filodemo. Sobre los estoicos: Papiro Herculanense $\mathrm{n}^{\circ} 339$, en MARTÍN GARCÍA (2008: 274-275).

11 Tres anécdotas son suficientes para mostrar este vínculo ambivalente entre el maestro tebano y el discípulo de Citio. En primer lugar, la celebración de este de haberse hecho discípulo de aquel: "«He tenido una feliz travesía ahora que he naufragado»: se aplica a los que han tenido éxito en contra de lo esperado. Pues Zenón de Citio lo dijo cuando abandonó a sus anteriores maestros y se convirtió en alumno habitual del filósofo Crates", La Suda, s. vv. "He tenido una feliz travesía...", en MARTín GARCía (2008: 274-275). De segundo, tendríamos el gesto simpático de Zenón de velar la cópula pública de su maestro con Hiparquía: "Y allí mismo, en un lugar concurrido, públicamente, bajo una luz clarísima, (Crates) se acostó con ella (Hiparquía) y públicamente hubiera desflorado a la virgen, que estaba dispuesta con igual firmeza, si Zenón no hubiera protegido en secreto a su maestro de las miradas del círculo de gente que los rodeaba, con un mantillo que tenía preparado", Apuleyo, Flóridas 14, en MARTín GARCía (2008: 508). Y en último lugar, el momento en que Zenón se distancia definitivamente de su maestro por no superar una prueba de desvergüenza: "El mismo Crates en cierta ocasión le dijo, para que la llevara, una olla de lentejas a Zenón de Citio, que era discípulo suyo. Y como Zenón ocultara bastante vanidosamente la olla en medio de la multitud, Crates la golpeó con el bastón y la rompió. Al derramarse entonces las lentejas por las piernas de Zenón y ruborizarse éste por ello, le dijo: «iFenicillo, ten resolución, porque no son ninguna cosa terrible sino lentejas!»”, Gnomologium Vaticanum 743, n. 384; en MARTín GARCÍA (2008: 506).

${ }^{12}$ Cf. PORTER (2020: 208-250).

${ }^{13}$ Sobre la relación de Cleantes y el cinismo: ANDRADE LEITE (2019). Respecto a Crisipo podemos hacer mención de su elogio de Antístenes; cf. Plutarco. Sobre las contradicciones de los estoicos 14, p. 1039 e-1040 a; en MARTín GARCÍA (2008: 172) y Diógenes; cf. Plutarco. Sobre las contradicciones de los estoicos 21, p. 1044 b, en MARTín GARcía (2008: 345). O de su agrado ante las ideas expuestas en la cínica Constitución política de Zenón; cf. Filodemo. Sobre los estoicos: Papiro Herculanense n. ${ }^{\circ} 339$, Col. XIII; en MARTín García (2008: 345).

Stylos. 2021; 30 (30); pp. 137-154; ISSN: 0327-8859; E-ISSN: 2683-7900 
encontramos el reconocimiento del cinismo como "el camino abreviado a la virtud", ${ }^{14}$ pero Antípatro, que le es contemporáneo, manifiesta horror ante algunas aseveraciones presuntamente diogénicas sobre política; ${ }^{15}$ Séneca, por su parte, no deja de hacer encomios de su amigo el cínico Demetrio retratándolo como un modelo de virtud, ${ }^{16}$ mostrando, además, admiración por algunos rasgos generales del cinismo, ${ }^{17}$ pero no deja de dirigir críticas severas a ciertas actitudes, incluso atreviéndose a poner a la figura más icónica del movimiento, a Diógenes, como ejemplo de estas; ${ }^{18} \mathrm{y}$, para culminar con los ejemplos, Marco Aurelio no tiene ninguna reserva en citar máximas cínicas por considerarlas provechosas, ${ }^{19}$ no obstante, podemos notar en Meditaciones que ve conveniente alejarse del estoicismo rudimentario de Diognetes, cercano al cinismo,${ }^{20}$ prefiriendo la discreta sabiduría de Rústico, ${ }^{21}$ discípulo de Epicteto.

Ahora bien, el modo en que Epicteto recogió la herencia cínica es particularmente interesante, y no apenas por ser el único de los estoicos del cual se conserva un discurso, por lo demás extenso y célebre, dedicado con exclusividad al cinismo, sino ante todo por el complejo dispositivo a través del cual se logra dar un lugar fundamental al cinismo en la visión de mundo estoica -lo que usualmente ha sido entendido como una mero mecanismo de "idealización" - ${ }^{22}$ a la vez que se ponen rigurosos límites a su propagación e

\footnotetext{
${ }^{14}$ D. L., VII 121 (2010: 273).

${ }^{15}$ Filodemo, Sobre los estoicos: Papiro Herculanense n. ${ }^{\circ}$ 339, en Martín García (2008: 274).

${ }^{16}$ Séneca. Epístolas a Lucilio 62, 3; Sobre la vida feliz 18, 3; Sobre los beneficios VII, 8-10; Sobre la providencia 3, 3; Cuestiones Naturales IV A, praef. 7, en MARTín GARCÍA (2008: 727-734).

${ }^{17}$ SÉNECA. Sobre los beneficios V 4, 3-4, en Martín García (2008: 370).

18 SÉNECA (1986: 217). Al respecto, revisar también el comentario a la quinta epístola del primer libro titulada "Evitar la singularidad y limitar los deseos", en DE FREITAS (2019: 209210).

${ }^{19}$ Marco Aurelio Vi 47 (1977: 126).

${ }^{20}$ Cf. GRIFFIN (2020: 264).

${ }^{21}$ Cf. HADOT (2013: 48).

22 Cf. Laurenti (1962: 501-513); Long (2020: 46); Billerbeck (1978); Goulet-CazÉ (1992 : 3913-1914); GRIFFIN (2020); CALOGERO (1984: 395-408).
}

Stylos. 2021; 30 (30); pp. 137-154; ISSN: 0327-8859; E-ISSN: 2683-7900 
impacto en el cuerpo social. Este dispositivo funciona de dos formas básicas: por un lado, de modo discreto e indirecto, a través de la intelectualización o virtualización de las prácticas performativas del cinismo convirtiéndolas en ejercicios de consciencia; y, por el otro, de un modo más explícito, como remodelación hermenéutica del personaje cínico, la cual no consiste tan solo ni fundamentalmente en edulcorarlo, limar sus asperezas u obviar su desfachatez, sino más bien en destacar su radical excepcionalidad, su extrema singularidad, siendo justo esta la que le permite, e incluso le exige, una conducta que sería inaceptable para el resto de los mortales. La primera de las formas, al no limitarse a un discurso dedicado exclusivamente al cinismo y extenderse a todo el corpus estoico de la era imperial, abarcando, además, no pocos rasgos propios del cinismo -que pasan, por si fuera poco, por un mecanismo complejo de estoicización-, requiere un trabajo que excede los límites de esta presentación, por lo que lo dejaremos para otra oportunidad. La segunda, la de destacar el carácter absolutamente excepcional del cínico, parece ser, en cambio, bastante característica del filósofo frigio y se encuentra delimitada a un discurso de las Disertaciones por Arriano y a algunas pocas menciones satelitales a éste, razón por la cual podremos examinarla con un poco más de cuidado.

Se podría objetar que en Séneca también puede hallarse cierta alusión a la excepcionalidad del cínico, pero, además de que ésta se limita apenas a la figura semi-legendaria de Diógenes y se establece respecto a un "nosotros" del que no podemos saber su alcance, dicha excepcionalidad se sostiene sobre algo tan contingente como lo es la posesión de una mayor fuerza ${ }^{23}$. En Epicteto, en cambio, la excepción cínica tiene un fundamento ontoteológico; se es cínico solo por voluntad divina. Epicteto comienza su disertación en torno al cinismo sosteniendo que "el que se aplica a tal asunto (el cinismo) sin la divinidad incurre en la cólera divina" ${ }^{24}$, e insiste en que el cínico

23 "Pero puesto que no tenemos tanta fuerza (como la de Diógenes), han de estrecharse ciertamente los patrimonios para que estemos menos expuestos a las injurias de la fortuna", SÉNECA, VIII 9 (1992: 46).

${ }^{24}$ EPICTETO, III, XXII 2 (1993: 319-320).

Stylos. 2021; 30 (30); pp. 137-154; ISSN: 0327-8859; E-ISSN: 2683-7900 
"ha de saber que ha sido enviado como mensajero de Zeus a los hombres"25. Más adelante advierte al que desea emprender este tipo de vida: "conócete a ti mismo, interroga a tu genio, no lo intentes sin la divinidad"26; y un poco después: “¿Qué es para el cínico el César o un procónsul? ¿O cualquier otro, excepto el que le ha enviado y a quien sirve, Zeus?"27. No deja de ser cierto que Epicteto no es el único en atribuir al cinismo un origen divino; Juliano, por ejemplo, sostiene que su auténtico fundador fue Apolo, al brindar a Diógenes el oráculo con el que se abanderó todo el movimiento: parakharáttein tò nómisma (alterar la moneda), pero esto no representaría una excepción, sino, por el contrario, la regla, en tanto que para el emperador la filosofía en general sería un don de los dioses fundado sobre otra máxima délfica: gnóthi seautón (conócete a ti mismo). ${ }^{28}$

Los especialistas han sabido percatarse de este mecanismo estoico de excepcionalización del cínico, y han entendido que fue usado para cuidar su presunta herencia socrática (como ya hemos explicado), para otorgarse por derecho de sucesión una serie de rasgos del cinismo cercanos a la moral popular romana que compensaban otros muy propios de la doctrina estoica que eran desagradables a la convención ${ }^{29}$ y para eximir al propio filósofo del pórtico de adoptar una vida cínica. ${ }^{30}$ En este sentido, desde un punto de vista estoico el hombre que procuraba la virtud podía iniciarse en la sabiduría del pórtico bastándole apenas su propia voluntad, por lo que el hacerse virtuoso o no era su responsabilidad, algo adjudicable a su carácter. En cambio, el cinismo, por muy loable que fuera, no era un tipo de vida filosófica cuya escogencia dependa de la libertad del sujeto, la cual en este caso se limitaría apenas a comprobar si en efecto él ha sido seleccionado por la divinidad para

\footnotetext{
${ }^{25}$ EPICTETO, III, XXII 23 (1993: 322).

${ }^{26}$ EPICTETO, III, XXII 53 (1993: 327).

${ }^{27}$ EPICTETO, III, XXII 56 (1993: 327-328).

${ }^{28}$ Cf. Juliano (1982: 115-146).

29 “(...) se habían conservado aquellas cualidades (cínicas) (...), y que parecían ventajosas en el contexto romano: hincapié de la enseñanaza práctica en el ejemplo, la elocuencia, la dureza física y la austeridad en general", GRIFFIN (2020: 269).

30 "Elevando el cinismo a un nivel religioso y a la condición de una existencia excepcional en el seno de la comunidad humana, Epicteto (...) dispensa al sabio estoico de tener que escoger si asume o no el papel del Perro", BiLLERBECK (2020: 274).
}

Stylos. 2021; 30 (30); pp. 137-154; ISSN: 0327-8859; E-ISSN: 2683-7900 
llevar la misión cínica. ${ }^{31} \mathrm{Si}$ los especialistas se limitaran a llamar idealización a este mecanismo en el que se distancia lo cínico haciéndolo encarnable solo por una excepcional mediación divina, entonces no podríamos no estar de acuerdo con ellos en que lo que hace Epicteto es idealizar. No obstante, su concepción de la idealización epictetiana del cínico no se limita apenas a esto, sino que suele hacer también referencia a una edulcoración de dicha figura, sobre todo en lo que respecta a la desvergüenza (anaidea) que la tradición le atribuye; "el impudor -afirma Billerbeck refiriéndose a los textos de Juliano y, en especialmente, Epicteto-, rasgo eminente de las anécdotas sobre Diógenes y que caracterizó la conducta real de los antiguos cínicos, tiende a eliminarse". ${ }^{32}$ No es extraño en absoluto que esta tesis se haya vuelto canónica, al menos si consideramos que en el pasaje de las Disertaciones al que más se hace alusión al momento de sostenerla dice explícitamente que uno de los rasgos más propios del cínico es lo contrario a la desvergüenza: "el cínico $(\ldots)$ ha de rodearse del pudor". ${ }^{33}$ Pero conviene revisar el pasaje completo en el que se inserta esta cita para poder comprenderla adecuadamente:

(Si has de ser cínico) que no te parezca hermosa una muchachita ni una opinioncita ni un muchachito ni un pastelito. Debes saber que los otros hombres se rodean de muros y casas y oscuridad cuando hacen una cosa de ésas y tienen muchas cosas que los oculten. Tiene la puerta cerrada, ha puesto a alguien ante la alcoba. «Si viene alguien, di que está fuera, que no tiene tiempo». El cínico, en lugar de todas esas cosas, ha de rodearse del pudor. Si no, perderá la compostura desnudo y en plena claridad. Eso es su casa, eso es su puerta, eso es quien

\footnotetext{
31 “ ¿Ves cómo ha emprendido semejante negocio? Primero coge un espejo, mírate los hombros, fijate en la espalda, en los muslos. (...) Piénsalo con más cuidado, conócete a ti mismo, interroga a tu genio (...)" (ЕРICTETO III, XXII 50-53 (1993: 327)).

${ }^{32}$ BILLERBECK (2020: 289).

${ }^{33}$ EPICTETO III, XXII 15 (1993: 321).
}

Stylos. 2021; 30 (30); pp. 137-154; ISSN: 0327-8859; E-ISSN: 2683-7900 
guarda su alcoba, eso es la oscuridad. Pues ni ha de querer este ocultar nada de lo suyo (si no, se acabó, se echó a perder su cinismo, su vivir al aire libre, su libertad; empieza a temer algo de lo externo, empieza a tener necesidad de algo que lo oculte) ni podrá cuando quiera. ¿Dónde se esconderá o cómo? Si por azar cae el educador común, el pedagogo, iqué no habrá de pasarnos! ¿Es posible, aun temiendo esto, confiar de todo corazón en ser el guía de los demás hombres? No hay medio, es imposible. ${ }^{34}$

Más que intentar hacer pasar al cinismo por un simple modus vivendi pudoroso, lo que hace Epicteto aquí es remodelar la interpretación común del cínico como sujeto desvergonzado. Esta remodelación epictetiana es posible gracias a un factor tan importante como pasado por alto: no se encuentra ninguna fuente clásica en la que algún cínico hable explícitamente a favor de la impudicia, y si bien es cierto que los fundamentos del cinismo suelen extraerse de puestas en escena, acontecimientos biográficos y gestos narrados a través de anécdotas, ${ }^{35}$ no deja de ser igual de cierto que la desvergüenza que el hermeneuta cree ver sostenida y defendida por el cinismo sea en realidad un error de interpretación de dichas escenificaciones cínicas. De hecho, llama la tención que en este pasaje lo primero que se señala no es el pudor del adepto al cinismo, sino su radical excepcionalidad, sustentada ésta en una auto-transparentación de la existencia, en un culto total de la luz, en una -como diría Glucksmann- eliminación sistemática de las sombras y el polvo. ${ }^{36}$ Es precisamente esta auto-exposición extrema, que para Epicteto es tan propia del cinismo, la que ha llevado a la tradición a entender el cinismo como un encomio de la desvergüenza, pero esto se debería, desde la perspectiva del estoico, a que se ha confundido un mero efecto con un presunto ob-

${ }^{34}$ EPICTETO III, XXII 13-18 (1993: 321).

${ }^{35}$ Sobre la importancia de la anécdota en el cinismo y en la retórica filosófica: OYARZúN (1996); específicamente la primera parte, titulada "Historia, anécdota, filosofía".

${ }^{36}$ GluCKSMANN (1982: 96).

Stylos. 2021; 30 (30); pp. 137-154; ISSN: 0327-8859; E-ISSN: 2683-7900 
jetivo; si el cínico defeca, orina, se masturba, pedorrea y copula en público esto no sería porque procure hacer gala de su desvergüenza y así atacar los principios nómicos del aidós, sino porque es inevitable que las funciones naturales del cuerpo, al no tener "muros y casas y oscuridad", queden ineludiblemente a la vista de los otros.

En este punto entran en juego dos rasgos muy propios de los cínicos: por un lado, la gran valoración de lo natural, la physis; y, por el otro, lo que he denominado en una ocasión previa "estrategia adiafórica" o de "indiferenciación de los espacios y los modos de comportamiento que suponen". ${ }^{37}$ La propuesta cínica de vivir según la Naturaleza, heredada por los estoicos ${ }^{38}$ y ridiculizada por autores antiguos ${ }^{39}$ y contemporáneos ${ }^{40}$ que no vieron en el cinismo sino un ingenuo asilvestramiento de la vida, es bien conocida y explica que a los cínicos no les parecieran vergonzosas de ningún modo las funciones fisiológicas. La "estrategia adiafórica", por su parte, consiste en una valoración ética de los actos en la que no se pretende diluir la distinción convencional de los lugares en los que dichos actos se realizan, especialmente la distinción tan fundamental en el ámbito de la vida ciudadana de lo público y lo privado; en otras palabras, el cinismo emprendería una valoración atópica de los comportamientos. Por ejemplo: “(...) decían -sostiene Elías sobre los cínicos- que si algo es bueno, se debe realizar en público y en privado, mientras que si no es bueno, no se debe realizar ni en público ni en privado"; ${ }^{41}$ por su parte, Diógenes Laercio, hablando de su homónimo de Sinope, narra que "solía hacerlo todo en público, tanto lo de Deméter como lo de Afrodita (...) «Si no es nada extraño almorzar, tampoco es extraño hacerlo en la plaza. Almorzar no es extraño, luego tampoco lo es hacerlo en la plaza»". ${ }^{42}$ También sabemos que Crates se paseaba por las casas de los ciu-

\footnotetext{
${ }^{37}$ DE Freitas (2019: 156).

${ }^{38}$ Sobre el concepto de Naturaleza en el estoicismo: LOPES SANTOS (2019: 219-233).

${ }^{39}$ El caso más ejemplar quizás sean los apuntes de Filodemo sobre la República diogénica: Sobre los estoicos: Papiro Herculanense $n^{\circ}$ 339. En MARTín GARCÍA (2008: 274-275).

${ }^{40}$ Cf. SAYRe (1948).

${ }^{41}$ Elías. “A las Categorías de Aristóteles” p. 111, 1-32. En MARTín GARCía (2008: 141).

${ }^{42}$ D. L., VI 69 (2010: 228).
}

Stylos. 2021; 30 (30); pp. 137-154; ISSN: 0327-8859; E-ISSN: 2683-7900 
dadanos del mismo modo en que se movía por la plaza pública, ${ }^{43}$ y que Demonacte fue enjuiciado por no creer que los misterios de Eleusis debieran permanecer en un ámbito de exclusividad. ${ }^{44}$

Este mecanismo de revaloración lo repite Epicteto al momento de examinar dos rasgos habituales de la vida cínica (bíos kynikós) que eran polémicos tanto desde el punto de vista estoico como desde el cívico-romano: la abstención de crear una familia (con la excepción de Crates e Hiparquía) ${ }^{45}$ y la indiferencia respecto a los asuntos políticos (si bien tenemos el llamativo caso de Favonio). ${ }^{46}$ En ambos casos la revaloración se sirve de un recurso retórico que tiene sus similitudes con la estrategia de indiferenciación espacial que acabamos de explicar, pero ahora se trata más bien de apelar a un universal que trivializa las particularidades: si el cínico no forma una familia es porque ya se encuentra en una relación familiar con la humanidad en su totalidad, relación ésta que engloba y hace que sean banales e incluso indiferentes las esferas familiares particulares. Después de hacer un retrato caricaturesco de la vida conyugal común con sus ridículos avatares (sobrellevar a los suegros, atender los reclamos del embarazo, llenarse de cacharros necesarios para el cuidado del niño, etc.), dice Epicteto del cínico: "él ha engendrado a todos los seres humanos, tiene por hijos a los hombres; por hijas a las mujeres. Así se acerca a todos, así se ocupa de todos. ¿O a ti te parece que insulta a los que se encuentra por entrometimiento? Lo hace como padre,

\footnotetext{
43 "Nunca le fue cerrada ninguna casa, ni hubo ningún secreto del padre de familia tan oculto que no permitiera a Crates intervenir oportunamente, convirtiéndose en el juez y árbitro de todos los litigios y altercados entre parientes", Apuleyo. "Floridas" 22, en MARTín GARCíA (2008: 514)

44 "El motivo de no haber participado en sus ceremonias de iniciación era porque si los misterios eran viles no se los hubiera ocultado a los iniciados, sino que les hubiera disuadido para que no los celebraran. Y si eran buenos los hubiera revelado a todos por filantropía”, LuCIANO (1981: 135).

${ }^{45}$ El propio EPICTETO (1993: 331) considera el caso.

${ }^{46}$ Favonio, seguidor de Catón y considerado cínico por su parrhesía, fue edil y pretor durante el Siglo I a.C. Goulet-CAzÉ (2020: 509) lo incluye en el catálogo de cínicos cuya autenticidad histórica ha sido confirmada. José A. MARTín GARCía (2008: 685-701), por su parte, recoge los fragmentos clásicos en torno al personaje en su recopilación Los filósofos cínicos y la literatura moral serioburlesca.
}

Stylos. 2021; 30 (30); pp. 137-154; ISSN: 0327-8859; E-ISSN: 2683-7900 
como hermano y como servidor del padre común Zeus". ${ }^{47}$ Lo mismo sucedería en lo referente a los asuntos políticos:

Bobo, ¿buscas mayor participación en política que la que él tiene? ¿O se presentará a hablar con los atenienses sobre ingresos o impuestos quien ha de dialogar con todos los hombres, igual con atenienses que con corintios o romanos, y no sobre recursos o sobre rentas, ni sobre la paz o la guerra, sino sobre la felicidad y la desdicha, sobre la bienaventuranza y la desventura, sobre la esclavitud y la libertad? ¿Y tú me preguntas si ha de participar en política un hombre que desempeña tan gran actividad ciudadana? $?^{48}$

Se observa en el pasaje cómo el quehacer cosmopolítico del cínico envuelve y termina por disolver la labor política convencional de dos modos: por un lado, extendiéndose a todo el cosmos y así haciendo indiferentes los asuntos de las polis particulares (sean estas Atenas, Corinto o Roma); y, por el otro, banalizando algunas inquietudes típicamente políticas (ingresos, impuestos) por medio de un desplazamiento de dicha labor a unos fundamentos éticos (la bienaventuranza, la libertad, etc.).

Los especialistas, con Billerbeck a la cabeza, se han percatado de esta estrategia epictetiana de reinterpretación positiva de estos rasgos polémicos vinculados a la familia y a la política ${ }^{49}$, pero en lo que respecta al tema de la desvergüenza, como hemos visto, han entendido que hay una omisión o eliminación de dicha característica, cuando en realidad aquí también se efectúa una remodelación hermenéutica: del mismo modo que el cínico no rechaza la familia, sino que toda la humanidad lo es; o que no evita las labores políti-

\footnotetext{
${ }^{47}$ EPICTETO, III, XXII 81-82 (1993: 332).

${ }^{48}$ EPICTETO, III, XXII 83-85 (1993: 332-333).

49 "El rechazo de la amistad, el matrimonio, la procreación y el compromiso político demandaba una reinterpretación positiva, si el cinismo, en especial entre los romanos, no debía hacerse sospechoso de ser un movimiento subversivo", BILLERBECK (2020: 274).
}

Stylos. 2021; 30 (30); pp. 137-154; ISSN: 0327-8859; E-ISSN: 2683-7900 
cas, sino que su quehacer cosmopolítico no se limita a ninguna polis específica; así mismo, el cínico no es desvergonzado, sino que en su exposición absoluta no hace nada vergonzoso. La dificultad de percibir esta continuidad interpretativa entre los diferentes rasgos que examina Epicteto se debe, sin duda, a que éste habla explícitamente de un pudor (aidós) cínico, siendo este, de hecho, el que permitiría vivir a los seguidores de Diógenes sin velo alguno. Considerando la gran cantidad de anécdotas en las que se narra la desfachatez de los adeptos al cinismo y el conjunto de fuentes tardías que sostienen que los cínicos (del griego kynikos, perruno) fueron llamados de este modo por imitar la desvergüenza de los perros,$^{50}$ es comprensible que esta descripción epictetiana que pone el acento en el pudor cause extrañeza. En este sentido es interesante el que Foucault haya cambiado de un año a otro su traducción e interpretación de este pasaje de las Disertaciones: en el curso del Collège de France de 1983, titulado El gobierno de sí y de los otros, el francés traduce aidós como "reserva", y agrega un larguísimo paréntesis en el que explica que dicho término no puede ser entendido como pudor o vergüenza. ${ }^{51}$ Un año después, en el curso El coraje de la verdad, en donde se emprende por primera vez en el corpus foucaultiano un análisis exclusivo sobre la vida filosófica de los cínicos, Foucault vuelve a citar íntegramente el pasaje de Epicteto, pero esta vez usando la traducción canónica de aidós, "pudor". ${ }^{52}$ El cambio de traducción fue causa de un cambio de interpretación del pasaje en particular y del cinismo en general: Foucault pasó de comprender la filosofía cínica desde un paradigma tradicional que pone el acento en su aspecto antinómico (por lo que el cinismo sería entonces un ataque contra todos los principios convencionales: el pudor, la civilidad, el respeto, el refinamiento cultural, el enriquecimiento, etc.) a uno bastante más original en el que el cínico solo invertiría dichos principios por una especie de radicalización paródica de los mismos. ${ }^{53}$ En continuidad con esto, si el cínico tiene comportamientos que desde la opinión común serían considerados impúdi-

\footnotetext{
${ }^{50}$ En Amonio, Olimpiodoro, Filópono y Elías encontramos explicitada esta tesis. Cf. MARTín GARCÍA (2008: 141-142).

${ }^{51}$ FouCAULT (2011: 303).

${ }^{52}$ FoucAult (2010: 309).

${ }^{53}$ Un estudio detallado sobre este mecanismo que descubre Foucault en el cinismo: DE FREITAS (2019).
}

Stylos. 2021; 30 (30); pp. 137-154; ISSN: 0327-8859; E-ISSN: 2683-7900 
cos, es precisamente porque ha radicalizado y expuesto materialmente el principio aceptado por la convención de la vida pudorosa, vida tan pudorosa que no tiene nada que ocultar, que se expone plenamente, solo resguardada por el pudor mismo, pudor que no solo lo abstiene de hacer cualquier cosa vergonzosa, sino también que, paradójicamente, lo impulsa a no ocultar nada de sí mismo, a mostrar que no tiene nada que esconder, y, por lo tanto, a convertirse desde el punto de vista de la opinión pública en un desvergonzado. ${ }^{54}$

La idea de que Epicteto pretendía quitar todo rasgo de desvergüenza en su retrato del cínico, desvergüenza que para Billerbeck y sus seguidores le sería sustancial a éste, es además reforzada por algunos pasajes en los que se insiste en la pulcritud y buena imagen del auténtico seguidor de la filosofía de Diógenes en contraste con los falsos cínicos que, según asegura el estoico, parecen mendigos ${ }^{55}$ Pero es igual de cierto que Epicteto deja ver el comportamiento escandaloso y desfachatado del filósofo perruno verdadero, y no solo en el apartado de la plena exposición, que ya implica un comportamiento excéntrico difícil de tolerar, sino incluso en aquellos pasajes en los que distingue al cínico auténtico del falso, quejándose de que éstos tan solo imiten a aquéllos en los actos considerados impúdicos, ${ }^{56}$ lo que obviamente significa que entiende esta supuesta impudicia como una peculiaridad más (aunque no definitoria) del cinismo. No se trata, entonces, de que Epicteto obvie un rasgo muy característico del cinismo como podría ser la desvergüenza (anaideia), o que intente ocultar esas actitudes que escandalizan a la muchedumbre, sino más bien argumentar que dichas actitudes solo son escandalosas y vergonzosas para quienes no han entendido que son la exposición de un hombre que se ha entregado a una vida pudorosamente transpa-

\footnotetext{
${ }^{54}$ Sobre esta paradoja del pudor: DE FREITAS (2019: 426-442).

55 "Como hacía Diógenes: andaba por ahí reluciente y por su propio cuerpo hacía volverse al vulgo. Un cínico miserable parece un mendigo. Todos se apartan de él, a todos desagrada. Y es que tampoco ha de mostrarse sucio, para tampoco por ello espantar a los hombres, sino que su sobriedad ha de ser limpia y atractiva", EPICTETO, III, XXII 81-82 (1993: 332).

56 “¿Nunca nos daremos cuenta de la grandeza ni nos representaremos en su justo valor el carácter de Diógenes, sino que nos fijaremos en los de ahora, en esos gorrones guardapuertas que no imitan a aquellos en nada, sino, en todo caso, en tirarse pedos y nada más?”, EPICTETO, III, XXII 80 (1993: 332).
}

Stylos. 2021; 30 (30); pp. 137-154; ISSN: 0327-8859; E-ISSN: 2683-7900 
rente. Y tan consciente está Epicteto de esta confusión de las mayorías sobre este punto en particular, que advierte al que se iniciará en el cinismo que la paciencia extraordinaria que exige el tipo de vida que emprende hará "que al vulgo le parezca desvergonzado y de piedra". ${ }^{57}$

En cualquier caso, si bien no hay aquí una omisión de rasgos sino un blanqueamiento -a través de una remodelación hermenéutica- de las características más intolerables del cinismo desde una perspectiva romana, lo cierto es que incluso así éste es posible bajo la condición ineludible de la excepcionalidad. Para un estoico del imperio, la interpretación positiva de los principios de vida cínicos apenas logran justificar las bondades de estar en su línea de sucesión filosófica, tanto más importante cuanto que esa línea conecta al estoicismo con Sócrates, pero esto no podía ser suficiente, dado que aún faltaría por explicar por qué sería necesaria una sabiduría distinta al cinismo si esta ya es tan provechosa. Aquí es donde entra en juego el carácter excepcional del cínico, su necesaria particularidad, la cual es justificada con motivos religiosos, incluso proféticos; que el cínico para Epicteto tenga una misión angélica, ${ }^{58}$ kataskópica, $^{59}$ episcopal ${ }^{60}$ y martirológica ${ }^{61}$ no solo libra al moderado estoico de tomar ese áspero "atajo a la virtud" 62 que es el cinismo, sino que brinda la posibilidad a las autoridades, filosóficas y políticas, de impugnar la autenticidad de cualquier cínico contemporáneo. En efecto, ¿quién podría probar que ha sido escogido desde el cielo para transparentar la propia existencia (y la de los otros), para ser el hombre que dice y atestigua la verdad y para vigilar los vicios del mundo.

\footnotetext{
${ }^{57}$ EPICTETO, III, XXII 100 (1993: 335).

${ }^{58}$ EPICTETO, III, XXII 23, 38, 69 (1993: 322, 325, 330).

${ }^{59}$ EPICTETO, III, XXII 38, 69 (1993: 325, 330).

${ }^{60}$ EPICTETO, III, XXII 72-73 (1993: 330-331).

${ }^{61}$ EPICTETO, III, XXII 88 (1993: 333).

${ }^{62}$ D. L., VI 121 (2010: 273).
}

Stylos. 2021; 30 (30); pp. 137-154; ISSN: 0327-8859; E-ISSN: 2683-7900 


\section{REFERENCIAS BIBLIOGRÁFICAS}

BANNERT, H. "Numismatisches zu Biographie und Lehre des Hundes Diogenes", Litterae Numismaticae Vindobonenses, (1979) 1: 49-53.

BILLERBECK, M. "El ideal cínico de Epicteto a Juliano", 270-290. En: R. Bracht Branham y Marie-Odile Goulet-Cazé (eds.), Cínicos. El movimiento cínico en la Antigüedad y su legado, Barcelona: Ariel, 2020.

- $\quad$ Epiktet Vom Kynismus, Leiden: E. J. Brill, 1978.

CAlogero, G. "Cinismo e stoicismo in Epitteto", Scritti minori di filosofía antica, 1984 Elecnchos suppl. 10: 395-408.

CiCERÓN. Acerca de los deberes, trad. Rubén Bonifaz Nuño, México D. F.: Universidad Nacional Autónoma de México, 2009.

DE FREITAS, J. H. El cinismo de Foucault. La verdad encarnada y sus gesticulaciones. Tesis doctoral defendida en la Universidad Complutense de Madrid, 2019.

DudLEY, D. A history of cynicism from Diogenes to the $6^{\text {th }}$ century A.D, New York: Gordon Press, 1974.

EPICTETO. Disertaciones por Arriano, trad. Paloma Ortíz García, Madrid: Gredos, 1993.

FELIU, S. Socráticos menores (cínicos, cirenaicos y megáricos), Valencia: Universidad de Valencia, 1977.

Foucault, M. El gobierno de sí y de los otros II. Curso del Collège de Frances (1983-1984), Buenos Aires: Fondo de Cultura Económica, 2010.

- $\quad$ El gobierno de sí y de los otros. Curso del Collège de France (19821983), Madrid: Akal, 2011.

GARCíA GUAL, C. La secta del perro, Madrid: Alianza, 2002.

GiAnNATONI, G. Socratis et Socraticorum Reliquiae, vol. 4, Napoles: Biblipolis, 1990.

GluCKSManN, A. Cinismo y pasión, Barcelona: Anagrama, 1982.

GOMPERZ, T. Pensadores griegos II, Barcelona: Herder, 2010.

Goulet-CAZÉ, M.-O. "Catálogo integral de los filósofos cínicos conocidos”. En: R. Bracht Branham y Marie-Odile Goulet-Cazé (eds.), Cínicos. El movimiento cínico en la Antigüedad y su legado, Barcelona: Ariel, 2020.

Stylos. 2021; 30 (30); pp. 137-154; ISSN: 0327-8859; E-ISSN: 2683-7900 
- $\quad$ "Le cynisme à l'époque impériale”, $A N R W, 1990$ 2, 36, 4: 2720-2833.

- "Le libre VI Diogéne Laërce: Analyse de sa structure et réflexions méthodologiques", ANRW 1992 2, 36, 6: 3913-1914.

Goulet, R. Y GOUlET-CAZE, M.-O. Le cynisme ancien et ses prolongements, París: Presses universitaires de France, 1993.

GRIFFIN, M. "El cinismo y los romanos: atracción y repulsión". En: R. Bracht Branham y Marie-Odile Goulet-Cazé (eds.), Cínicos. El movimiento cínico en la Antigüedad y su legado, Barcelona: Ariel, 2020.

HADOT, P. La ciudadela interior, Barcelona: Alpha Decay, 2013.

HÖISTAD, R. Cynic hero and cynic King. Studies in the cynic conception of man, Uppsala: University of Uppsala, 1948.

JENOFOnTE. Recuerdos de Sócrates, trad. Juan Zaragoza, Madrid: Gredos, 1993.

Juliano. Discursos VI-XII, trad. José García Blanco, Madrid: Gredos, 1982.

KRUEGER, D. "El desvergonzado y la sociedad. La impudicia de Diógenes en la cultura romana imperial". En : R. Bracht Branham y Marie-Odile Goulet-Cazé (eds.), Cínicos. El movimiento cínico en la Antigüedad y su legado, Barcelona: Ariel, 2020.

LAERCIO, D. Vidas y opiniones de los filósofos ilustres, trad. Luis-Andrés Bredlow, Zamora: Lucina, 2010.

LANDA, J. Éticas de crisis: cinismo, epicureísmo, estoicismo, Barcelona: Paso de barca, 2015.

LiTE, C. "A vida cínica de Cleantes de Assos: amor ao labor como vida filosófica”, Phaos: Revista De Estudios Clásicos 2019 19: 1-18.

LONG, A. "La tradición socrática: Diógenes, Crates y la ética helenística". En: R. Bracht Branham y Marie-Odile Goulet-Cazé (eds.), Los cínicos. El movimiento cínico en la Antigüedad y su legado, Barcelona: Ariel, 2020.

LoPes SANTOS, R. "Sobre o conceito estoico de natureza", Problemata: $R$. Intern. 2019 Fil. V. 10 n. 1: 219-233.

LuCiANO. Obras I, trad. Andrés Espinosa Alarcón, Madrid: Gredos, 1981.

MARCo Aurelio. Meditaciones, trad. Ramón Bach Pellicer, Madrid: Gredos, 1977.

MÁRsico, C. Cínicos, Buenos Aires: Galerna, 2019.

Stylos. 2021; 30 (30); pp. 137-154; ISSN: 0327-8859; E-ISSN: 2683-7900 
MARTÍN GARCÍA, J. A. Los filósofos cínicos y la literatura moral serioburlesca, Madrid: Akal, 2008.

MOLES, J. "El cosmopolitismo cínico" en Cínicos. El movimiento cínico en la Antigüedad y su legado. En: R. Bracht Branham y Marie-Odile Goulet-Cazé (eds.), Los cínicos. El movimiento cínico en la Antigüedad y su legado, Barcelona: Ariel, 2020.

Oyarzún, P. El dedo de Diógenes, Santiago de Chile: Dolmen, 1996.

PORTER, J. I. "La filosofía de Aristón de Quíos". En: R. Bracht Branham y Marie-Odile Goulet-Cazé (eds.), Cínicos. El movimiento cínico en la Antigüedad y su legado, Barcelona: Ariel, 2020.

SAYRE, F. Diogenes of Sinope. A Study of Greek Cynicism, Baltimore: J. H. Furst Company, 1948.

SÉNECA. Tratados morales I, trad. José M. Gallegos, México, D. F.: Bibliotheca Scriptorum Graecorum et Romanorum Mexicana, 1992.

SÉNECA. Epístolas morales a Lucilio, trad. Ismael Roca Meliá, Madrid: Gredos, 1986.

Stylos. 2021; 30 (30); pp. 137-154; ISSN: 0327-8859; E-ISSN: 2683-7900 